\title{
Marine mammals in Turkey
}

BAYRAM ÖZTÜRK ${ }^{1}$ AND AYAKA AMAHA ÖZTÜRK ${ }^{2}$

1 Faculty of Fisheries, Istanbul University, Ordu Cad. No: 200, Laleli - Istanbul, Turkey (ozturkb@istanbul.edu.tr), and ${ }^{2}$ Science and Technology Institute, Istanbul University, Ordu Cad. No: 200, Laleli - Istanbul, Turkey

SUMMARY: Turkey is surrounded by four seas of different oceanographic characteristics. However, the knowledge about marine mammals, especially cetaceans, in these waters has been limited. The systematic investigation on marine mammals in the Turkish waters was started in 1987. In the Black Sea and Marmara Sea, three odontocete species, Delphinus delphis, Tursiops truncatus, and Phocoena phocoena, are known to occur. Bycatch in the turbot fishery is the main threat for $P$. phocoena. In the Aegean and Mediteranean Sea, there are eight odontocete species: $D$. delphis, $T$. truncatus, Stenella coeruleoalba, Globicephala melas, Grampus griseus, Pseudorca crassidens, Physeter catodon, Ziphius cavirostris, and a single mysticete species, Balaenoptera physalus.

Besides, our study confirmed that one of the critically endangered pinniped species, the Mediterranean monk seal, Monachus monachus, still survives in the Black Sea and Marmara Sea. It has fragmented populations in the Aegean and Mediterranean Seas and their status is critical due to loss of habitats and deliberate killing.

\section{KEY WORDS: Black Sea, Marmara Sea, Aegean Sea, Mediterranean Sea, Mediterranean monk seal, cetaceans, bycatch}

\section{INTRODUCTION}

Turkey has a long coastline, more than $8300 \mathrm{~km}$, and several islands. It is also surrounded by four seas of different oceanographic characteristics; the Black Sea, Marmara Sea, Aegean Sea, and Mediterranean Sea (Fig. 1). However, the cetacean study in Turkey has a relatively short history. A research program for data collection and field observation has been carried out since 1987 by Faculty of Fisheries, Istanbul University, and currently by Turkish Marine Research Foundation.

The aim of this paper is to review the status of cetaceans accoridng to different seas in Turkey and that of the Mediterranean monk seal in the Turkish waters.

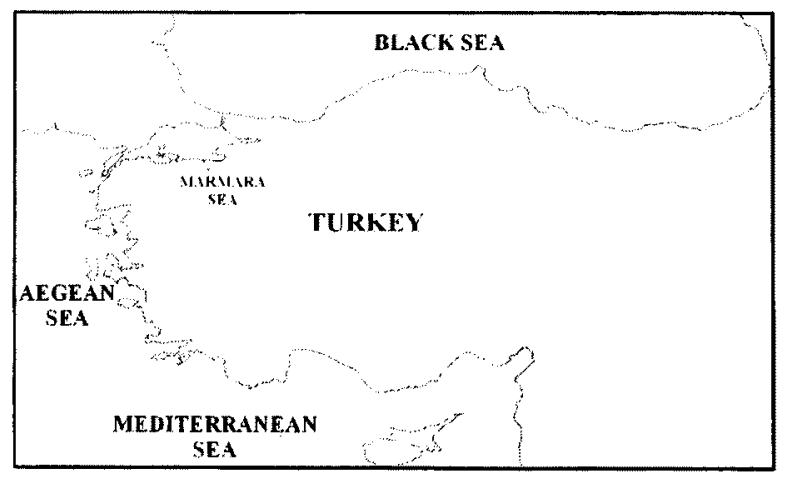

Fig. 1 Turkey surrounded by four seas.

\section{Cetaceans}

\section{The Black Sea}

Although there has been a long history of dolphin fisheries in the Black Sea, mainly for the production of oil, there has not been any systematic study with the cooperation among riparian countries. The dolphin harvesting in the Black Sea was banned by 1963, excluding Turkey. In 1983, Turkey also stopped dolphin fisheries and put dolphins under the legal protection.

There are three species of dolphins in the Black Sea, namely Delphinus delphis, Tursiops truncatus and Phocoena phocoena. The most common species is $D$. delphis, followed by $P$. phocoena, then $T$. truncatus. ${ }^{1)} P$. phocoena seems to prefer colder water and less saline water since it is rarely observed in the Canakkale Strait, nor in the shallow western part of the Marmara Sea, where there is strong influence of warm and salty Mediterranean water.

The population trends of the Black Sea dolphins are not known accurately. The last population survey was made in 1987 off the Turkish coast and an estimated total population of three species combined was 454,440 individuals. ${ }^{2)}$ However, this study covered only the Turkish side of the Black Sea and there were some problems with their survey method. A stock assesement of these three species is urgently 
needed with the cooperation of other Black Sea countries.

Bycatch and water pollution are main threats for the Black Sea dolphins in the Turkish coasts. Especially, the bycatch in the turbot fishiery is a serious threat for $P$. phocoena in the Turkish coastal water. In the western coast of the Turkish Black Sea in 1993-1997, the cetacean bycatch due to the turbot fisheries was reported by Öztürk et al. ${ }^{3)}$ In this study, except one specimen of $T$. truncatus, all samples were $P$. phocoena. Most specimens were immature animals, with the body length less than $130 \mathrm{~cm}$. Bycatch occurred with the bottom gill nets for turbot fisheries from April to June. The mesh size of the net is $22 \mathrm{~cm}$ and its length is $150 \mathrm{~m}$. Maximum depth of the setting of the net is about $80 \mathrm{~m}$. It is necessary to collect more data covering the whole Turkish coast in the Black Sea to regulate the turbot fishery. Besides, the Black Sea fishermen claim that the decline of the pelagic fish stocks is due to the ban of the dolphin hunting. Therefore, an education program is suggested for the local people in order to implement any conservation measures for dolphins.

The Black Sea is known as one of the most polluted seas in the world mainly due to the input of the Danube River. ${ }^{4)}$ The dolphins are under the treat of such pollution. The concentrations of organochlorine compounds, particularly DDTs and HCHs, in $P$. phocoena in the Turkish Black Sea was relatively high compared to the same species in the other areas. ${ }^{5)}$ To understand the long-term effect of the pollution on the cetaceans, it is important to monitor the pollution level in these animals.

A national program for the conservation of the Black Sea dolphins was prepared in $1994,{ }^{6}$ ) and it consists of four sections, research and monitoring program, establishement of the special protected areas, enforcement of the fisheries regulations and promotion of the public awareness campaign.

\section{The Marmara Sea}

The Turkish Straits, namely the Istanbul Strait (Bosphorus), the Marmara Sea, and the Canakkale Strait (Dardanelles), constitute a biological corridor for dolphins as well as for pelagic fish between the Black Sea and Mditerranean Sea. ${ }^{7}$ In the Marmara Sea, three cetacean species of the Black Sea, D. delphis, $T$. truncatus, and $P$. phocoena, are known to occur.

There is seasonal migration of cetaceans between the Aegean Sea and the Black Sea, through the Straits, in spring and autumn, following the prey fish, such as anchovies and horse mackerels. Currently, however, both the Canakkale Strait and Istanbul Strait actually act as a barrier againist cetaceans because of the heavy sea traffic. Moreover, all resident population of common and bottlenose dolphins in the Canakkale and Istanbul Strait no longer exist. ${ }^{7)}$

In the Marmara Sea, cetaceans occur over the entire area, except in the deepest part where there is less fish resource. ${ }^{8)}$ They are observed more often around the islands, probably due to greater sigthing effort and also to the high productivity of the area.

Cetacean stranding in the Marmara Sea was examined by Öztürk et al. ${ }^{9)}$ From 1993 to 1998, a total of 16 stranded animals of $P$. phocoena, $T$. truncatus, D. delphis and Stenella coeruleoalba were found. The cause of death for seven animals was determined as bycatch. Though a stranding of $S$. coeruleoalba was observed, an observation of live animals has not been reported yet. Therefore we consider the occurrence of this species was accidental.

The main threats for cetaceans in the Turkish Straits System are the heavy marine traffic, thus the loss of habitats and pollution.

\section{The Aegean and Mediterranean Sea}

In the Aegean Sea and Mediterranean Sea, nine cetacean species are known to occur. Those are $D$. delphis, T. truncatus, $S$. coeruleoalba, Globicephala melas, Grampus griseus, Pseudorca crassidens, Physeter catodon, Ziphius cavirostris and Balaenoptera physalus. ${ }^{\mathrm{I}}$ P. catodon is known to occur off Kemer-Antalya, which is one of the deepest areas of the Mediterranean Seas. ${ }^{1)}$

Cetacean strandings in the Aegean and Mediterranean coasts of Turkey were reported by Öztürk and Öztürk. ${ }^{10)}$ During 1990-1997, a total of 23 strandings were recorded. However, they assumed this figure should be more as many strandings are not reported due to the lack of effective stranding network.

Loss of habitats due to the coastal activities is the main threat for the dolphins in these seas.

Furthermore, the bycatch of the swordfish driftnet fiheries in the Aegean and Mediterraean coast of Turkey poses one of the threats for some cetacean species, such as $S$. coeruleoalba, $T$. truncatus, and $G$. griseus. ${ }^{11)}$ The swordfish fishing season lasts only two months, May and June. Mesh size of the driftnet used for the swordfish is $240-260 \mathrm{~mm}$ and the total length of the net is $1000-1500 \mathrm{~m}$ on average and the depth is $4 \mathrm{~m}$. The driftnet is set in the depth of $6-7$ $\mathrm{m}$ in general. 


\section{Mediterranean Monk Seal}

The Mediterranean monk seal, Monachus monachus, is one of the most critically endangered species on the world. ${ }^{12)}$ The remaining population is estimated as about 300 to 400 individuals in the world. ${ }^{13)}$ In the Aegean and Mediterranean Sea, there are some subpopulations scattered among the coastal caves and islands between Turkey and Greece.

In the Black Sea and Marmara Sea, the monk seals are on the verge of extinction for several reasons, such as loss of habitats, small size of the metapopulation, and capture for commercial purpose, which is currently not practiced any more. Only a few individuals were determined in the western Black Sea and small islands of the Marmara Sea. ${ }^{14)}$ However, the habitat protection is still important in these regions.

Öztürk $^{15)}$ identified 41 individuals during the study period between 1991 and 1996 in the Agean and Mediterranean Sea, among them 28 individuals survived till 1996, while 13 were dead. Only four pups were determined to survive. Except for two individuals in the Bodrum Peninsula, all monk seals were single individuals. Therefore, the population of the monk seals is not stable in the Aegean Sea. Main causes of the decline of the monk seal population were deliberate killing, loss of habitats due to coastal development, and overfishing. ${ }^{16)}$ The Aegean and Mediterranean fishermen complain the net damage made by the monk seals. This hostility has sometimes resulted in deliberate killing. An educational program and compensation for damaged nets are both needed to prevent such killing.

A pilot project in Foca, on the Aegean Sea coast of Turkey, still continues to protect the Mediterranean monk seals. Fisheries and shipping activities in that area are totally forbidden. ${ }^{17}$ )

In spite of the massive coastal construction, small islets and isolated beaches and caves are still seal habitats in the Aegean and Mediterranean Sea, especially, small islets in the Bodrum Peninsula such as Kiremit Islands, Cavus Islands, and Kardak Islands. For the Mediterranean Sea, one of the most important seal habitats is Cilician Basin, including Northern Cyprus territory.

\section{CONCLUSIONS}

The occurrence of cetacean species in the Turkish waters is summarized in Table 1.

There here arecetacean species living in the whole Mediterranean Sea basin, which includes the Black $\mathrm{Sea}^{18)}$ and 10 of them are observed in the Turkish waters. Other four species, namely, Balaenoptera acutorostrata, Orcinus orca, Megaptera novaeangliae, and Steno bredanensis, have not been observed in the Turkish coastal waters.

Table 1 Presence of cetacean species in the Turkish waters.

\begin{tabular}{lcccc}
\hline \hline Species & $\begin{array}{c}\text { Black } \\
\text { Sea }\end{array}$ & $\begin{array}{c}\text { Marmara } \\
\text { Sea }\end{array}$ & $\begin{array}{c}\text { Aegean } \\
\text { Sea }\end{array}$ & $\begin{array}{c}\text { Mediterranean } \\
\text { Sea }\end{array}$ \\
\hline Delphinus delphis & + & + & + & + \\
Tursiops truncatus & + & + & + & + \\
Phocoena phocoena & + & + & - & + \\
Stenella coeruleoalba & - & - & + & + \\
Grampus griseus & - & - & + & + \\
Pseudorca crassidens & - & - & + & + \\
Globicephala melas & - & - & + & + \\
Ziphius cavirostris & - & - & + & + \\
Physeter catodon & - & - & + & + \\
Balaenoptera physalus & - & - & + & + \\
\hline +: present, -: absent & & & &
\end{tabular}

A well-coordinated network for strandings as well as for sightings is necessary to get more information since the coastline of Turkey is too long to cover for one or two institutions. We have organized several meetings involving fishermen, harbour masters, coast guards, and NGOs to establish a stranding network in Turkey. A general consensus was made to establish a database in the Turkish Marine Research Foundation.

For the conservation of the dolphins in Turkey, education for public people and fishermen, enforcement of fisheries regulations, and protected areas should be made. However, some of the Turkish fishermen complain the net damage made by dolphins and they demand the compensation from the government. Cetaceans are under the legal protection since 1983 in Turkey, however, dolphin-fisherman interaction has not always been good. To implement the cetacean conservation program, it may be necessary to consider the above compensation.

For the conservation of the Mediterranean monk seal, the strategies are based on four elements. These are in situ protection; establishment of the special protected areas, mitigating delierate killings, management of the coastal fisheries, and mass public awareness campaigns, mostly for fishermen, local people, harbour authorities, coast guards, school teachers and students.

\section{ACKNOWLEDGMENTS}

Authors thank to TUBITAK, Istanbul University Research Fund and Turkish Marine Research Foundation for their invaluable contributions. 


\section{REFERENCES}

1. Öztürk B. Balinalar ve Yunuslar. (Whales and Dolphins.) Anahtar Yayinlari, Istanbul. 1996. (in Turkish)

2. Celikkale S, Ünsal S, Durukano đu F, Karacam H, Düzgünes $\mathrm{E}$. Size and distribution of dolphin populations in the Black Sea. Doga Tur. J. Zool. 1989; 13(3): 189-196.

3. Öztürk B, Öztürk AA, Dede A. Cetaceans bycatch in the western coasts of the Black Sea in 1993-1997. In: The Abstracts of the 13th Annual Conf. of European Cetacean Society. 1999: 134.

4. Mee LD. The Black Sea in crisis; a need for concerted international action plan. Ambio 1997; 21: 278-286.

5. Tanabe S, Murdhusree B, Öztürk AA, Tatsukawa R, Miyazaki N, Özdamar E, Aral O, Samusun O, Öztürk B. Persistent organochlorine residues in harbour porpoise (Phocoena phocoena) from the Black Sea. Marine Pollution Bulletin 1997; 34(5): 338-347.

6. Öztürk B. The Turkish national programme for the conservation of the Black Sea dolphins. In: Öztürk B (ed). Proc. Int. Sym. Marine Mammals of the Black Sea, 27-30 June 1994, צ́tanbul. UNEP, UNDP, and Istanbul University, Istanbul. 1996; 108-109 .

7. Öztürk B, Öztürk AA. On the biology of the Turkish straits system. Bulletin de l'Insitut océanograhique, Monaco 1996; No Spécial 17: 205-221.

8. Öztürk B, Öztürk A. Preliminary study on dolphin occurrrence in the Turkish Strait System. In: Evans P, Parsons E, Clark S (eds). Proceedings of the 11th Annual Conference of the European Cetacean Society, Stralsund, Germany. The European Cetacean Society, Kiel. 1997; 79-82.
9. Öztürk B, Dede A, Komut O. Cetacean strandings in the Marmara Sea. In: The Abstracts of the 13th Annual Conference of the European Cetacean Society, 1999: 258 .

10. Öztürk B, Öztürk AA. Cetacean strandings in the Aegean and Mediterranean coasts of Turkey. Rapp. Comm. int. Mer Medit. 1998; 35: 476-477.

11. Öztürk B, Öztürk AA, Dede A. Dolphin bycatch in the swordfish driftnet fishery in the Aegean Sea. Rapp. Comm. int. Mer Medit. 2001; 36: 308.

12. IUCN. IUCN Red list of Threatened Animals. IUCN, Gland, Switzerland. 1996.

13. Aguilar A. Status des Populations de Phoque Moine (Monachus monachus) de Méditerranée. CAR/ASP, Tunis. 1999.

14. Öztürk B. Investigations on the distribution of the population of the Mediterranean monk seal Monachus monachus (Hermann, 1779) in the Marmara Sea. Aegean University, Science Faculty, Serie B. 1994; 16/1: 845-851.

15. Öztürk, B. 1998. Monitoring of the Mediterranean Monk Seals in the Turkish Coast of the Aegean Sea. Rapp. Comm. int. Mer Medit. 1998; 35: 570-571.

16. Öztürk B. Mediterranean monk seal mortality in the Turkish waters during 1986-1996. In: Abstracts of Workshop on the Biology and Conservation of the World's Endangered Monk Seals, Monaco, 19-20 January 1998. 1998: 26.

17. Öztürk B, Dede A. Present status of the Mediterranean monk seal (Monachus monachus Hermann, 1779) on the coast of Foca in the Bay of Izmir (the Aegean Sea). Turkish J.Mar. Sci. 1995; 1(2/3): 95-107.

18. Beaubrun $\mathbf{P}(\mathrm{ed})$. Atlas préliminaire de distribution des cétacés de Méditerranée. Musée Océanographique Monaco, Monaco. 1995. 